\title{
VIA DE MÃO DUPLA PARA A URGENTE LUSITANIDADE: TRAMAS HISTORIOGRÁFICAS QUE ANEXARAM O SUL DO BRASIL À IDENTIDADE NACIONAL NO CONTEXTO DO ESTADO NOVO ${ }^{1}$
}

João Batista Bitencourt bitencourt.jb@gmail.com

\begin{abstract}
RESUMO: Nos anos 30 e 40 do século XX a historiografia catarinense e sul riograndense passou por reformulações que procuraram adequar o passado dos dois Estados ao padrão nacionalista vigente e construir uma versão da formação histórica estadual que dissipasse com as suspeitas que pairavam sobre o perfil étnico e o padrão identitário de suas populações em relação à brasilidade. Nos dois Estados houve um forte investimento na visibilização das tradições lusitanas, mas os impulsos que nortearam os historiadores de Santa Catarina e do Rio Grande do Sul não foram os mesmos. Toma-se como fio condutor para refletir sobre tais questões o texto, Laguna e Rio Grande, de Osvaldo Rodrigues Cabral.
\end{abstract}

PALAVRAS-CHAVE: historiografia; identidade; nacionalização.

\section{1- LAgUnA - Rio GRANDE}

Francisco Xavier, Manoel Gonçalves Ribeiros, Francisco Vicente Ferreira, Sebastião Francisco, Antônio Lopes Cardoso, José Pinto Bandeira, João Rodrigues Prates, João Braz, Domingos Gomes Ribeiro, assim como outros moradores da Laguna das primeiras décadas do século XVIII, reaparecem novamente nas tramas da vida em 1940. Chamados a auxiliar naquela contemporaneidade por meio de suas existências já vividas em outro tempo; pelas cenas da história são conclamados a tornarem-se cadáveres produtivos, zumbis, mortos-vivos entre o ontem e o atual, para que mais uma vez fizessem eles um percurso rumo ao sul. Pela pena de Osvaldo Rodrigues Cabral são exigidos na cena de outra história que os selecionou, Cabral ressuscita os mortos e os faz saltarem do passado para a atualidade para que ao falarem sobre o tempo de suas existências salvem seus descendentes naquele agora; o historiador os reabilita para brigarem por ele, defendê-lo nos dilemas que enfrentava em seu próprio tempo; cria ele uma comunidade entre os vivos e os mortos, uma cidade comum - a Laguna lusitana - entre o passado e o presente. O caminho que fizeram no século XVIII volta a ser percorrido naquele momento por Cabral que, arrastando consigo os seus

\footnotetext{
* Doutor em História Doutor em História (UFRGS). Professor na Universidade Federal do Maranhão.
} 
ancestrais, torna-os despojos que asseguram sua herança, o espólio do vencedor, e com eles promove seu “cortejo triunfal”. (BENJAMIN, 1994, p. 225.)

Esses nomes fazem parte do que ficou conhecido como o "coeficiente lagunista" na formação étnica do Rio Grande do Sul; moradores de Laguna que se estabeleceram no então Continente de São Pedro nas primeiras décadas do século XVIII. Todos esses nomes, assim como outros, figuram no texto Laguna e Rio Grande apresentado por Osvaldo Rodrigues Cabral no III Congresso Sul Rio-Grandense de História e Geografia, em 1940. Laguna e Rio Grande apresenta, em seis pequenas partes, algumas relações entre Laguna e o Rio Grande do Sul no século XVIII, sendo cinco pequenos textos e um anexo com transcrição de documentos do "Livro de Registro de Ordens Reaes e mais Papeis e Cousas que devem ser Registradas na Câmara da Vila de Santo Antônio dos Anjos da Laguna". A cada item o historiador registra um tipo de situação capaz de mostrar fortes laços ligando o Estado sulino à cidade catarinense. Seja a mudança no caminho do gado, saindo do litoral, como se vê no item I, ou os litígios quanto às cobranças de impostos sobre as passagens dos rios que dividem os dois Estados do sul em função da indefinição de seus limites, apresentados no item IV.

Em Laguna e Rio Grande encontra-se uma preocupação que acompanhará a trajetória do historiador e marcará profundamente grande parte de suas obras dos anos 30 aos 50, algo que ele próprio chamou de a vitória da colonização açoriana em Santa Catarina. (CABRAL, s. d.)

Os anos trinta do século passado iniciaram com algumas marcantes mudanças no cenário político e cultural catarinense, o conhecimento de alguns desses acontecimentos permite um melhor entendimento do contexto que fomentou o discurso de valorização da lusitanidade em geral e, em particular, a produção historiográfica de Cabral. Essas mudanças no plano da produção intelectual podem ser colocadas sob um itinerário que, na historiografia estadual contemporânea, vai da Invenção do litoral, expressão cunhada por Araújo (1989) para definir o sentido das intervenções urbana em Florianópolis e da produção cultural sobre o litoral na Primeira República, à Invenção da açorianidade, termo com o qual Flores (1997) sintetizou o esforço em estabelecer um discurso positivo sobre os traços culturais resultantes da colonização açoriana do litoral, nos anos 40 . Assim, de invenção à invenção, tem-se em Santa Catarina um deslocamento quanto aos parâmetros delineadores da identidade estadual.

A instalação do regime republicano em Santa Catarina culmina com a chegada aos postos do poder público estadual de uma nova leva de políticos que controlaram, sob a legenda do Partido Republicano Catarinense, os rumos da administração pública por toda a Primeira República. 
Notadamente, os dois personagens que despontaram como lideranças absolutas tinham fortes relações com as áreas de colonização alemã do vale do Itajaí e região nordeste do Estado. Lauro Müller era natural de Itajaí, filho de imigrante teuto, e Hercílio Luz natural de Desterro, porém tendo sua aparição política a partir de Blumenau. (MEIRINHO, 1982. CORRÊA, 1990.) A ascensão do novo grupo político combina com o bom desempenho econômico da região que representavam, pois cidades de colonização teuta como Joinville e Blumenau passaram a assumir a liderança econômica catarinense.

No momento em que ocorreu a ascensão das áreas de colonização teuta em Santa Catarina, o fim do século XIX, emerge no cenário nacional uma nova mentalidade sobre o país. De uma elite de característica romântica e voltada para o interior, que buscava uma identidade nativa, tem-se o surgimento de um cosmopolitismo. A idéia de acompanhar a civilização européia aportava no Brasil trazendo transformações de toda ordem. Urbanização, trabalho livre, república, liberalismo, civilidade, davam o tom de que se pretendia um novo país; que vencesse o "atraso" e acompanhasse o ritmo de desenvolvimento do norte europeu. Era a chegada em grande escala dos ideais de modernização no Brasil, os quais carregavam também uma perspectiva de governo que pretendia gerenciar as multidões; daí criava-se a população como objeto das ações de governo e, compondo essa, um padrão ideal de homem. (SEVCENKO, 1989)

A modernidade almejada, os sonhos de ver o país caminhando dentro dos princípios que regiam as nações exportadoras do modelo de progresso, esbarrava nos mais diversos entraves e um deles era particularmente caro aos intelectuais da época: como "vencer o atraso" com uma população tida como incapaz. Era a partir dessa questão que intelectuais se preocupavam em produzir uma nova imagem do ser nacional. Para os articuladores desse discurso, o atraso nacional, encontrado na comparação com o norte europeu, revelava o retardado estágio civilizatório em que se encontrava o Brasil. A realidade evolutiva, sob essa lógica, estava ligada a dois elementos que justificavam o "atraso": meio e raça. A questão meio poderia ser vencida pela intervenção na paisagem, já a questão raça esbarrava no problema tempo. Partindo das categorias explicativas do evolucionismo, o Brasil, fruto das três raças, teria que esperar a vitória do mais forte, ou seja o elemento europeu. Dito de outra forma, apostava-se na miscigenação enquanto branqueamento, como forma de apagar da população brasileira os caracteres negróides e indígenas. Assim, a sociedade brasileira viria a ser uma civilização européia nos trópicos com a fusão das três raças, sendo que desse processo de mestiçagem deveria resultar a superioridade do branco. Isso impediria que o ser brasileiro resultante da fusão apresentasse sinais de degeneração como a indolência e a 
incapacidade moral. Daí a valorização da imigração européia como forma de acelerar e garantir o branqueamento e, por conseguinte, a eliminação das "raças inferiores". (ORTIZ, 1994)

Além da imagem de condição essencial para vencer o "atraso" pelo aprimoramento da raça, visão que dela tinham os intelectuais das teorias raciológicas, a imigração branca, sob o olhar de outros grupos, ligava-se também a certos fatores vistos como afirmativos. Por exemplo, uma nova forma produtiva. Pois apesar do olhar direcionado de cada facção da sociedade, tais discursos estavam ligados a valores como progresso, ordem, civilidade, que acompanhavam as perspectivas da modernidade daquele momento. A veiculação de que a produção eficiente se dava pela mão de obra livre requeria uma nova roupagem sobre o sentido do trabalho, de sofrimento físico passa a ser encarado como elemento gerador de riqueza. Progresso, civilidade, ordem, estariam intrinsecamente ligados a uma nova simbologia do trabalho, agora dignificante. Qualificado como laborioso, inteligente e vigoroso o imigrante europeu esboçava então o caráter moral e democrático presentes no novo valor do trabalho, imagem que era a antítese do negro visto como ocioso, pouco amante do trabalho e indisciplinado. (SALLES, 1986)

A imigração européia - com algumas variações dependendo de onde partisse o discurso sobre ela - formava, no Brasil do final do século XIX, um quadro de composição afirmativa e, no caso de Santa Catarina, essa representação ganhava ainda mais força. Diferente de outras regiões do Brasil onde a imigração era uma proposta de futuro, no Estado catarinense era uma realidade presente, mais que isso, uma realidade próspera. Se para os intelectuais das teorias raciais o imigrante surge como algo a se somar à parte branca da população, ou seja, a parcela descendente de portugueses, pois o seu avesso estava na forma como o negro era concebido, em Santa Catarina dão-se outras relações. Toda essa discussão tinha como pano de fundo a chegada das novas leis do capitalismo internacional e era destinado ao elemento branco as qualidades para melhor adaptar-se a elas, como amor ao trabalho, perseverança e espírito empreendedor. Em Santa Catarina, por outro lado, tais atributos estavam vinculados aos imigrantes da colonização teuta do vale do Itajaí e da região nordeste, inferindo sobre a população do litoral de ascendência lusitana uma imagem próxima a dos negros para o discurso nacional.

As colônias de imigrantes alemães instaladas no vale do Itajaí e região nordeste, segundo a historiografia econômica catarinense, despontaram a partir de 1880 quando seus empreendimentos industriais fizeram a economia estadual ultrapassar seu caráter de subsistência e acompanhar os desdobramentos do desenvolvimento industrial brasileiro. Essa transformação é creditada à "mentalidade dos alemães" que teria sido o elemento motor do observado avanço. Contrastando 
com as cidades do litoral, onde a economia manteve seu caráter agrícola com a produção de mandioca, sem haver grande evolução técnica no sistema de fabrico, as cidades das regiões de colonização germânica passaram da manufatura a efetivas indústrias com grande dinamismo. A título ilustrativo, basta lembrar que em 1907, Joinville, Blumenau, Brusque e Itajaí concentravam 101 dos 173 estabelecimentos industriais existentes no Estado. (BOSSLE, 1988, p. 47. CUNHA, 1982)

Políticos e intelectuais catarinenses do final do século XIX, inspirados pelas doutrinas em voga e pelos valores burgueses, encontravam na população de ascendência lusitana do litoral uma "indolência nativa" que a incapacitava física e moralmente. Isto é, uma incapacidade para acompanhar os ritmos da nova ordem capitalista e de produzir o progresso assim como era pensado. Esses políticos e intelectuais problematizaram o "fatalismo das raças sem vontade", para encontrar no estilo de vida do habitante do litoral, padrões de comportamento que o identificavam como incapaz, doente, indolente e atrasado. $\mathrm{O}$ habitante do litoral catarinense, principalmente a parcela pobre da população, era designado como pertencente a uma sub-raça, na qual se identificava características negativas como a preguiça, a falta de perseverança e a incapacidade moral; uma raça degenerada. Falava-se que o açoriano do litoral havia sofrido uma degeneração fisiológica. (ARAÚJO, 1989)

A revolução de 30 e os desdobramentos na política catarinense dela advindos podem, então, ser entendidos como um marco de mudança nos rumos desses discursos. Desde o amanhecer republicano, passadas as complicações da Revolução Federalista e da Revolta da Armada, a política estadual manteve-se em relativa concórdia. Praticamente até o início dos anos 20 os políticos de destaque concentravam-se no Partido Republicano Catarinense que se manteve até aquela época sem efetiva oposição. Houve, é certo, um número nada pequeno de disputas internas, mas sempre apaziguadas no interior do próprio partido. Lauro Severiano Müller, Chefe Supremo do Partido, controlava-o da esfera federal e Hercílio Pedro da Luz comandava-o no âmbito estadual. A pretensa harmonia existente no Partido Republicano Catarinense foi rompida a partir de 1918 quando Hercílio Luz chegou pela segunda vez ao governo do Estado e assumiu a presidência do partido, limitando o espaço de atuação de Müller. (CORREA, 1990)

Em 1920, buscando impedir a candidatura de Nereu Ramos, filho do ex-governador e vicepresidente do partido Vidal Ramos, à Câmara Federal, Hercílio provocou uma dissidência no Partido Republicano Catarinense. Vidal e Nereu, juntamente com outros políticos a eles ligados, formaram um grupo de oposição, a Reação Republicana, e posteriormente, em 1926, Nereu alia-se 
ao Partido Democrático de São Paulo para mais tarde, em 1929, criar uma nova agremiação, a Aliança Liberal, ligada ao grupo gaúcho de Getúlio Vargas. Nas eleições de 1930 o Partido Republicano permaneceu no comando do governo do Estado com a eleição de Fúlvio Aducci, mas esse é deposto com o movimento gaúcho que chegou a Santa Catarina apoiado pelos Ramos. Com a derrubada do governo de Fúlvio Aducci, assumiu o comando político catarinense o General Ptolomeu de Assis Brasil e, em seu governo, a Aliança Liberal tornou-se verdadeiramente um partido político, o Partido Liberal Catarinense de 1931, tendo como primeiro presidente Nereu Ramos. Um ano depois de formado, o partido já enfrentou cisões. Nereu era favorável ao movimento constitucionalista de São Paulo enquanto seu Primo Aristiliano Ramos liderava os que apoiavam Getúlio. Porém como o partido formalmente apoiava Getúlio, Nereu afastou-se da presidência. Com o fim do movimento paulista Assis Brasil deixou o executivo estadual passando a interventoria a seu irmão, o major Rui Zobaram, desencadeando uma reação dos liberais que, com o apoio de Flores da Cunha, interventor do Rio Grande do Sul, derrubam Zobaram que foi substituído por Aristiliano Ramos. No governo de Aristiliano a ala do partido ligada a Nereu que apoiou os paulistas foi anistiada e retornou ao partido, que voltou a ter a presidência de Nereu em 1934. No ano seguinte, disputaram as eleições ao governo dois candidatos do Partido Liberal; o interventor Aristiliano Ramos e seu primo, o presidente do partido. A Assembléia Legislativa elegeu Nereu que, em 1937, com o golpe do Estado Novo permaneceu à frente do governo catarinense como interventor federal e continuou no cargo até 1945, quando do fim daquele regime. (PIAZZA, 1994, p. 569, 649. CORRÊA, 1988)

Quando da Revolução de 30 os campos de poder político em Santa Catarina estavam, então, assim configurados: os Ramos eram oposição ao governo estadual de Fúlvio Coriolano Aducci, representante do Partido Republicano, agremiação controlada pelos Konder que detinham o governo desde o último mandato de Hercílio Luz. Deste modo, a Revolução de 30 surge em Santa Catarina como uma inversão de grupos políticos no comando do Estado, transformando um controle político que perdurara por boa parte da última década. É possível ler nessa inversão, os delineamentos de uma étnico-geografia do poder político estadual.

A ocupação do território catarinense deu-se de forma desarticulada e em parcelas descontinuas que acabaram por formar um Estado que é um verdadeiro mosaico étnico-cultural. A começar pela colonização portuguesa no litoral, seguiu-se a ocupação do Planalto Serrano em função do comércio do gado e, posteriormente, a chegada dos açorianos e madeirenses. Mais tarde, já no século XIX, chegaram as levas de imigrantes alemães e italianos que se instalaram no vale do 
Itajaí e região nordeste, tendo os italianos também forte presença no sul. Isso sem contar as outras levas imigratórias e migratórias que a partir do final do século XIX deram uma nova configuração populacional a Santa Catarina com a ocupação da região oeste e centro-oeste. No momento da Revolução de 30, o Vale do Itajaí e o Planalto Serrano, eram as áreas de onde provinham as forças políticas que disputavam o controle estadual e duas famílias polarizavam essa disputa, os Konder e os Ramos. A primeira de ascendência teuta, de Itajaí, ligada às zonas industriais do nordeste catarinense, e a segunda de Lages, de ascendência lusitana, ligada à indústria madeireira e pecuarista do planalto.

Um Estado fragmentado étnica, econômica, geográfica e culturalmente foi a resultante do processo de colonização esparso, descompassado e surgido de diferentes momentos e intenções. A descentralização produziu "zonas geo-econômicas" autônomas, com desenvolvimentos bastante distintos. Como ilhas isoladas sem um ponto de convergência, uma vez que até mesmo a capital não se compunha como centro em torno do qual gravitassem as demais áreas, as regiões isoladas tinham inclusive a natureza a vencer. Pois, não há em Santa Catarina um rio navegável no sentido horizontal que integre o território, assim como as serras do Mar e Geral compõem-se numa barreira natural a separar o planalto do litoral. Com a unificação do mercado nacional, esboçada a partir de 1930, e a maior definição da relação centro-periferia, a economia catarinense tendia a ficar ainda mais desarticulada internamente com a relação direta das "zonas" com o eixo Rio-São Paulo. Visto que cada uma delas possuía seu próprio escoadouro, porto ou ferrovia, e assim possuíam um sistema de ligação interno - na própria zona - e um externo - para fora do Estado - mas não havia um sistema de integração das "zonas" entre si. (SOUTO, 1980. SILVA, 1978)

O problema da fragmentação foi objeto de preocupação político-administrativa desde o início da República, quando os governantes procuraram instituir uma imagem coesa de Santa Catarina. Contudo, os governos da Primeira República não conseguiram avançar em grande medida na integração do Estado, pelo menos essa era a tônica dos discursos dos novos ocupantes do poder que ascenderam com a Revolução de 30.

Criticando o parco empenho dos governos até então em produzir a integração, o governo catarinense a partir da Revolução de 30 e principalmente de 1935 a 1945, período do governo de Nereu Ramos, investiu em grande proporção na perspectiva integracionista, tanto no sentido físico como cultural. A administração de Nereu Ramos é notadamente marcada pelo investimento em estradas e pela nacionalização do ensino junto às populações das colônias de imigrantes. Segundo Campos (1992, p. 33), além do uso da propaganda e escolarização, o grande número de obras 
assistencialistas de seu governo tinha o interesse de criar uma população homogênea, disciplinada e principalmente brasileira face às intenções do Estado Novo e ao surto de desenvolvimento industrial ocorrido no Estado entre os anos de 1920 a 40. Era o interesse de construir um referencial único como forma de forjar um operário ideal e "catarinense por excelência". Assim a matriz do que deveria ser o homem catarinense, em função da série de transformações observadas, não era mais o imigrante alemão. As novas forças políticas estavam empenhadas em promover a integração do Estado e compor uma imagem homogênea de sua população, uma identidade única acima das variações culturais, com um novo padrão que, em princípio, não dispensava a então reconhecida operosidade do imigrante, mas passava pelo caráter nacionalista do luso-brasileiro.

$\mathrm{Na}$ virada política catarinense, a partir do movimento de 30, o historiador Oswaldo Rodrigues Cabral encontrou o momento propício para positivar a participação do luso-brasileiro na formação da sociedade catarinense. Se os "inventores do litoral" tiveram a Primeira República como período favorável a um discurso afirmativo do imigrante alemão e seus descendentes, os "inventores da açorianidade" encontravam no período pós-Revolução de 30 um campo fértil e propício a absorver uma produção que desse ao luso-brasileiro do litoral catarinense uma imagem positiva. Trata-se de uma luta de representação (CHARTIER, 1990) em que estava em jogo a identidade catarinense. Sem uma imagem única dominante, a identidade estadual variava em consonância com o poder de definir e nomear o que era ou não legitimamente pertencente e definidor dessa identidade. Em razão de ser uma verdade submetida ao vitorioso daquele agora, que envolvia relações de poder do presente, é que permitiu a Cabral apresentar sua versão da história da formação de Santa Catarina da qual selecionou no passado elementos capazes de justificar os posicionamentos que só a vantagem no jogo de poder de sua contemporaneidade permitiu-lhe falar. Melhor, não só falar, mas principalmente ser ouvido e reconhecido.

Em 1948 foi realizado o Primeiro Congresso de História Catarinense como parte da comemoração do segundo centenário da colonização açoriana de Santa Catarina. Cabral, respondeu pelo cargo de $1^{\circ}$ vice-presidente da comissão executiva do evento e nele se destacou apresentando dois trabalhos: Os Juizes de Fora (Nossa Senhora do Desterro) e Os Açorianos. Ainda em homenagem à data festejada publicou, também em 1948, a obra Assuntos insulanos uma "contribuição ao estudo do povoamento de Santa Catarina pelos casais açorianos e madeirenses". O Congresso buscava dar maior visibilidade e valorizar elementos da herança luso-brasileira como a língua, por exemplo, para diminuir o peso do dito fracasso econômico da colonização açoriana no litoral catarinense. No discurso que proferiu quando da colocação da pedra fundamental do 
monumento comemorativo ao segundo centenário da chegada dos casais açorianos, em 20 de fevereiro de 1948, Cabral falou:

Se as fainas agrícolas não conduziram à vitória esperada, se os açorianos não imitaram os gregos, dos quais dizia Homero que lavravam o solo espirando com delícia o cheiro da terra revolvida de frescor, se não realizaram eles o sonho de Silva Paes, limitados nas suas esperanças à criação de núcleos agrícolas, entretanto alicerçaram obra de maior envergadura: - o açoriano e o madeirense, pela sua descendência, conservaram para o Brasil este pedaço de chão sobre o qual o castelhano ousou pôr o pé, mas não logrou deitar a mão, nem descansar a cabeça. (CABRAL, 1948, p. 38)

Os "inventores" da açorianidade, em geral, aceitavam o fracasso econômico dos açorianos, no tocante ao empreendimento agrícola. Segundo eles, as dificuldades colocadas aos colonos como o aliciamento de pessoal para compor as tropas de defesa do território, a pobreza do solo, o baixo valor de mercado de seus produtos, os confiscos da produção pelo governo e o isolamento das populações, eram as razões que explicavam a decadência experimentada pela colonização açoriana. Cabral, no entanto, via essas como causas secundárias. Na sua visão o principal motivo estava no fato do açoriano ter uma tradição pastoril e não agrícola, era a partir dessa constatação que explicava o sucesso dos açorianos no Rio Grande do Sul. O congresso de 1948 era então, segundo o historiador, um meio de mostrar "pelo estudo do passado e pela observação do presente" que em Santa Catarina:

... a dominante de sua trama social é o elemento luso, originário daquelas ilhas [Açores e Madeira], cuja capacidade de absorção dos elementos alienígenas ainda permanece intacta e integralmente eficiente, impondo os seus costumes, a sua maneira de falar, os seus hábitos, preponderantemente, no meio social. (CABRAL, 1948-b)

Chegara, então, o tempo de tornar visível e valorizar na historiografia a imigração açoriana que, segundo Henrique da Silva Fontes, presidente da comissão executiva do Congresso, até então não tinha recebido "devido relevo". Para Fontes, se os imigrantes açorianos lograram as expectativas no sentido agrícola, deveria se reconhecer que "cresceram e triunfaram, contribuindo para a rija base de cultura luso-brasileira, que enfrentou e absorveu ou modificou outras culturas, sendo elemento de segurança e de progresso para o Brasil.” (FONTES, 1948)

No discurso que proferiu na solenidade do dia 20 de fevereiro, Cabral foi buscar uma imagem bíblica para em tom épico finalizá-lo. Na imagem trazida à luz pelo historiador, tomada como leitura da imigração açoriana, os luso-brasileiros deveriam ser reconhecidos como os justos 
possuidores de Santa Catarina, não só porque seus ancestrais foram os primeiros colonos, mas principalmente pelo fato de terem sido eles portugueses. Isso os tornava o povo eleito, previamente escolhido como se um direito divino os tivesse ungido. Assim, deveriam os herdeiros daqueles colonizadores marcar tal domínio, elevando as obras de seus ancestrais. Como uma profecia que naquele momento se cumprira, o historiador evocou palavras do livro do Êxodo: "Darei a vossa posteridade toda esta terra de que vos falei, e vós a possuireis para sempre". Se a ocupação açoriana não tinha encontrado reconhecimento até então, tinha a mesma posteridade que a fez vislumbrar a necessidade de perpetuá-la, como requisito para continuidade da credibilidade daquele passado e de sua própria sobrevivência. Ao que parece, Cabral está referindo-se a uma dimensão simbólica de posse, possuir é servir de imagem identitária ao Estado, nomeá-lo, dizer dele o que é, talvez seja por essa razão que fala em termos de descendência. Cabe à "posteridade" dos colonos açorianos a posse da terra. Em outras palavras, pode-se pensar que o historiador estava a proferir que cabe ao lusobrasileiro o papel de ser o catarinense, pois aquele era o momento no qual seus descendentes tinham o poder de positivar e perpetuar os feitos de seus ancestrais. Isto é, estava se colocando a disputa por uma imagem ideal do homem catarinense que, naquele momento, cabia ao luso-brasileiro falar mais alto. Segundo, Manuel de Paiva Boléo, professor da Faculdade de Coimbra convidado a participar do evento, tal congresso "constituiu uma necessidade no Estado de Santa Catarina, onde a cultura luso-brasileira perigosamente enfrentou a cultura alemã. A finalidade suprema, embora não expressa, era a de mostrar para os outros Estados da União, a brasilidade de Santa Catarina”. (BOLÉO apud: FLORES, 1997, p. 115)

A ameaça era presente, fazendo-se necessária a busca por fórmulas de auto-afirmação, aceitação e credibilidade. Cabral então apoiava seu discurso em outros já sacralizados, estetiza-o, estabelecendo-o sobre patamares de compreensão anteriormente colocados e amplamente divulgados, pronunciando-o dentro de uma linguagem que adentra a um mundo de idéias presentes no imaginário social. Ao referir-se à antigüidade clássica e aludir uma passagem do livro sagrado dos cristãos, ocupa-se das mais reconhecidas convenções da tradição ocidental e nela insere a colonização açoriana como uma saga legendária - tanto no sentido de lenda, de narrativa épica, como no de legenda, indicação explicativa, norteadora -. Adentrar ao universo simbólico reconhecido concebendo novos elementos na esteira dos já consensuais era uma maneira de obter vantagem nas lutas de representação pela imagem do catarinense, na tentativa de impor a definição da identidade estadual de acordo com os interesses da lusitanidade. Ou seja, caminhar por outros discursos formulando uma nova discursividade é forjar um efeito de evidência e autenticidade para 
uma nova enunciação semântica, como dispositivo de garantia da recepção. (MAINGUENEAU, 1993. BOURDIEU, 1998)

Tido como um marco da iniciativa de criar um discurso positivo acerca do papel desempenhado pelo colono açoriano na construção de Santa Catarina, o Congresso chega a ser o coroamento dessa questão, visto que já estava sendo divulgada desde pelo menos o início do Estado Novo e quando de sua realização Osvaldo Rodrigues Cabral era Deputado Estadual, Nereu Ramos, que apoiou o congresso, ocupava a vice-presidência da República e seu sobrinho Aderbal Ramos da Silva era o governador do Estado. Apesar do fim do Estado Novo, os políticos e intelectuais que propagavam a lusitanidade catarinense estavam ocupando cargos de grande influência. Sem contar que o Congresso, assim como as outras comemorações, foi promovido pelo Instituto Histórico e Geográfico de Santa Catarina e patrocinado pelo poder público estadual e municipal. (BASES, 1948) Deve-se levar em conta ainda a questão simbólica do festejo pela passagem daquela data, como forma de re-fundação do tempo para inscrevê-la não só na história como também na memória dos catarinenses. "Antídoto do esquecimento" a memória é igualmente um instrumento de poder, o controle sobre a recordação social legitima as identidades manipuladas, fazendo-se mecanismo de dominação. (LE GOFF, 1994, p. 423-483) Assim, não bastava impor a herança açoriana como a melhor, ou a imagem catarinense, era necessário perpetuar essa tradição e inviabilizar a ascensão de outros possíveis pretendentes ao posto.

O aparecimento do médico Osvaldo Rodrigues Cabral como historiador ocorreu em 1937 com a publicação de Santa Catarina: história e evolução na Coleção Brasiliana da Cia. Editora Nacional. Foi sua primeira publicação de cunho histórico, uma história geral do Estado. Mas assuntos como povoamento e colonização já ocupavam considerável espaço do volume, revelando a preocupação do autor com o problema da compartimentação de Santa Catarina ao procurar identificar as diferentes paisagens e os diferentes tipos de habitantes. (CABRAL, 1937) Nos anos posteriores, Cabral lançou outros trabalhos historiográficos que se enquadravam de forma bem específica na perspectiva de valorização da lusitanidade e, deve-se salientar, a maioria deles publicados pela Imprensa Oficial do Estado. Ao que parece, Nereu Ramos procurou manter os intelectuais catarinenses mais destacados junto ao seu governo, apoiava e incentivava financeiramente as agremiações culturais que naquele momento são avivadas: Associação Catarinense de Imprensa, Academia Catarinense de Letras e, a mais atuante de todas, o Instituto Histórico e Geográfico de Santa Catarina, que estava praticamente desativado. 
A valorização da açorianidade que levou ao Primeiro Congresso de História Catarinense estava, já há algum tempo, sendo divulgada por Cabral. Uma obra marco dessa sua preocupação é $A$ vitória da colonização açoriana de 1941, publicada na revista Cultura política do Distrito Federal e também em separata pela Imprensa Oficial do Estado Santa Catarina. Nela, o autor apresenta sua tese de que o açoriano fracassado foi aquele que insistiu em permanecer na atividade agrícola. Não tendo índole de lavrador, o açoriano que se desligou da agricultura teve outra sorte, desempenhando com destaque atividades nas profissões liberais, na política, no comércio e nas artes. Para além da parcela bem sucedida, o que ressalta Cabral é o papel do habitante do litoral como guardião do padrão moral luso e, assim sendo, ninguém mais que ele poderia dizer-se vitorioso, pois em meio à multiplicidade étnica que formou a população catarinense, o colonizador lusitano conseguiu impor sua cultura e fazer de Santa Catarina um Estado plenamente brasileiro. Desse modo, afirma o historiador, é ele o "espírito da sociedade" catarinense e legou, através dos seus descendentes, as "linhas mestras do complexo social de Santa Catarina", por isso nem o sucesso econômico de outras etnias - "alienígenas" como costuma frisar - apagariam os "marcos da sua vitória": (CABRAL, s. d.)

A "vitória" da colonização açoriana em Cabral é também a sua vitória. No início deste artigo ocupou-se da imagem benjaminiana da história para pensar o "cortejo triunfal" que empreende o historiador lagunense ao convocar seus ancestrais a refazerem o caminho ao sul. Cabe aqui a outra dimensão da assertiva de Benjamin; os que no agora vencem, vencem em todos os tempos, já que a história é uma representação do passado "saturada de agoras". (BENJAMIN, 1994, p. 22-232) Os que na atualidade são portadores da voz legitima de dizer o que deve ou não pertencer à história, fazem-se os herdeiros dos vencedores. Assim, a vitória da qual se refere não é tão somente a de seus antepassados lusitanos mas também, e talvez principalmente, sua própria vitória; o sucesso dos defensores da colonização portuguesa do litoral catarinenses que tinham o momentos oportuno para divulgarem a identidade do Estado desde o ponto de vista da lusitanidade. E o lagunense Cabral, entusiasta de sua terra natal, não deixaria de aproveitar o contexto positivo para valorizar sua cidade.

Laguna não recebeu um número muito elevado de casais açorianos; esse incremento populacional não teve para o município a mesma dimensão e importância quanto o foi para a Capital. Cabral, então, constrói a importância da lusitanidade lagunense já anteriormente à chegada dos insulanos. Desse modo, a valorização da ascendência portuguesa de Laguna passava por outros caminhos, mesmo porque tinha outras intenções, respondia a outras inquietações. 
O texto que Cabral apresentou no congresso de 1940 em Porto alegre, ao que parece, tinha um alvo bem direcionado. O historiador catarinense queria mostrar como a lusitanidade do Rio Grande do Sul passava por Laguna. Cidade do litoral, apresentava ela os mesmos problemas de desempenho econômico que sustentava o discurso desqualificador surgido na Primeira República, sem contar que enfrentava ainda dentro da questão econômica problemas de outra ordem, dificuldades agravadas com o aumento da produção carbonífera. Essas encontravam eco no desenvolvimento nacional e estadual, mas davam-se sob relações bem localizadas. O país estava vivendo um governo nacionalizador de construção da identidade brasileira, de fortalecimento do sentimento patriótico, e embora a nacionalidade fosse pensada como uma cultura resultante do "cadinho das raças", tinha em última instância a supremacia do componente português. ${ }^{2}$ O governo federal que empreendia o movimento nacionalista partia do Rio Grande do Sul, Estado cuja ocupação territorial lusa deu-se a partir de Laguna. Cabral, então, trazia à luz uma história que, fornecendo elementos provedores da lusitanidade sul riograndense, promovia o reconhecimento de sua cidade natal.

Cabral inicia o texto afirmando categoricamente que "resultou do desenvolvimento do comércio do gado e das necessidades dele decorrentes a prematura decadência da vila de Santo Antônio dos Anjos da Laguna.” (ANAIS, 1940, v. 3, p. 1895) Estampa uma linha direta entre o desempenho econômico do Rio Grande do Sul e a não prosperidade da cidade. O desenvolvimento da pecuária no sul, segundo sua análise, necessitava vencer dois desafios para se afirmar: estabelecer uma “criação racional", não mais prear e sim constituir fazendas produtoras, e facilitar o acesso aos centros consumidores. Das soluções encontradas teria resultado o "sacrifício" do progresso lagunense. Inicialmente exaurindo sua população para ocupar o "caminho do litoral", estabelecendo estâncias, fixando os sesmeiros que dinamizaram a economia e asseguraram a posse da terra. E posteriormente, com a busca de um trajeto mais rápido aos mercados, pois o novo caminho afastava-se do litoral e retirava a vila da rota de comércio do gado. Assim as soluções encontradas para o desenvolvimento do Rio Grande do Sul levaram ao "definhamento" de Laguna. O historiador então cobre de louros o destino trágico da cidade, afirmando que ao "sacrificar" seu progresso serviu “para maior glória d'El-Rei”. (ANAIS, 1940, v. 3, p. 1895-1910) Não era a primeira vez que apresentava sua visão épico-trágica para a história da cidade, em outros textos já havia afirmado que Laguna viu definhar seu futuro em favor dos ideais da coroa lusitana. No ensaio Laguna, de 1939, a vila é mostrada como uma "sentinela avançada no extremo sul, amparando e 
assistindo a expansão lusitana e, com o sacrifício de sua vida e pela audácia de sua gente, deu o Rio Grande ao Brasil”. (CABRAL, 1939, p. 122)

Tudo sugere que Laguna e Rio Grande era uma espécie de cobrança. Cabral reivindicava uma dívida de gratidão do ilustre Estado vizinho para com sua terra. Aquele parecia o momento adequado a exigi-la, a situação favorecia a busca da notoriedade possível, engrandecer, creditar-lhe honras e fazê-las reconhecida para além das fronteiras catarinenses. Essa impressão torna-se ainda mais aparente com o desenrolar do texto. Dividido em cinco partes Laguna e Rio Grande junta elementos capazes de estabelecer uma relação bastante próxima entre a cidade e o Estado gaúcho, impregnada de idealismo lusitano. Além do primeiro item no qual o autor afirma que do progresso econômico e da garantia da lusitanidade do Rio Grande do Sul provêm os fatores da decadência de sua cidade natal, os demais também procuram reafirmar essas considerações mostrando, por exemplo, que o "êxodo dos lagunistas" ocorreu por mais de uma vez. Um desses momentos relatados diz respeito às disputas entre Portugal e Castela pela Colônia do Sacramento que, segundo o autor, exauriram Laguna, com o recrutamento de seus homens e o confisco de suas montarias. A decadência da vila é sempre apresentada como prova de lealdade à Coroa e defesa do domínio territorial luso, sobrando espaço para estabelecer laços com o Rio Grande, pois os que retornavam do conflito voltavam com a vontade de tornarem-se estancieiros no sul.

Sua investida ao sul recobriu-se de grande êxito. Teve ele atuante participação no congresso de 1940, recebendo inclusive moção de congratulação, distinção feita a alguns notáveis como Gilberto Freyre. (ANAIS, 1940, v. 1, p. 305) Darcy Azambuja, relator do parecer de sua tese disse dela merecer "franco louvor", que seu "erudito autor" relatou com proficiência e clareza o "quadro da íntima ligação entre Laguna e o Rio Grande de S. Pedro", ressaltando o valor da "velha póvoa catarinense, berço de tantas estirpes ilustres" do Estado sulino. (ANAIS, 1940, v. 1, p. 182) Na sessão do dia 8 de novembro quando foi lido o parecer de sua tese, Aurélio Porto, historiador gaúcho de reconhecido prestigio, solicitou um "voto especial de louvor à terra lagunense, donde vieram os desbravadores do Rio Grande." Cabral na ocasião discursou, recebendo calorosos aplausos da platéia ao proferir: "Laguna muito se orgulha de seu dileto filho, o Rio Grande". (ANAIS, 1940, v. 1, p. 286)

Cabe-nos agora percorrer o outro sentido desta via de mão dupla e entender o que fazia os intelectuais sul rio-grandenses acolherem com tamanho entusiasmo a relação Laguna e Rio Grande apresentada por Cabral. 


\section{2- Rio GRANDE - LAGUNA}

Em 1934, quando da comemoração dos 110 anos de imigração alemã no Estado do Rio Grande do Sul, o governador Flores da Cunha, decretou o dia 25 de julho feriado estadual pela passagem daquele acontecimento e, prestigiou com sua presença, os festejos realizados pelos teutobrasileiros. Como também, dois anos mais tarde, foi presidente de honra do Instituto GermanoBrasileiro, agremiação criada na capital gaúcha para estreitar as relações entre o Brasil e a Alemanha. Por essa mesma época, em Santa Catarina, o governador Aristiliano Ramos tomava medidas nada amistosas para a população de ascendência germânica. Fazendo observar o domínio da língua nacional pelos professores das escolas privadas, alterando a taxação físcal sobre investimento econômico - de tal forma que atingia preferencialmente a atividade industrial da zona de colonização alemã - e dividindo o território do município de Blumenau em mais quatro municípios menores. (GERTZ, 1987, p. 65-6)

Diferente de Santa Catarina, onde as questões políticas foram um forte motivo a fazer com que a nacionalização tivesse precoce aparição, no Rio Grande do Sul a campanha de transformação dos hábitos culturais dos imigrantes e seus descendentes surgiu efetivamente só mais tarde. Aqui está se falando sobre o processo de nacionalização das colônias de imigrantes instaladas no sul do país, das quais as de ascendência teuta foram o alvo preferencial de intervenção durante o Estado Novo.

Diferente do que ocorreu em Santa Catarina, no Rio Grande do Sul não houve alterações na estrutura política com a Revolução de 30, tendo em vista que esse movimento teve lá seu início, permanecendo no comando do Estado o mesmo grupo político, herdeiro de Borges de Medeiros chefe político que praticamente controlou o governo estadual por quase toda a Primeira República, deixando-o apenas em 1928 quando passa-o a Getúlio Vargas -. (GERTZ, 1987, p. 41) Bem como não havia naquele Estado problemas de isolamento de diferentes "zonas geo-econômicas", o que levou os teutos e seus descendentes a uma maior integração à sociedade gaúcha.

Havia, no Rio Grande do Sul, uma ligação bem mais afinada entre as colônias agrícolas e os centros urbanos e, dentro dessa relação, Porto Alegre ocupava uma posição privilegiada, pois a capital era igualmente o centro escoadouro da produção agrícola colonial. Esse intercâmbio promoveu a maior integração dos teutos. Quando dos avanços da modernidade porto-alegrense, por exemplo, estavam os teuto-brasileiros envolvidos com o desenvolvimento burguês que deslocava 
capital do comércio para a industrialização. Ao contrário do que ocorreu em Santa Catarina, o desempenho econômico dos teutos no Estado sulino, durante a Primeira República, fazia-os ainda mais integrados à sociedade e não os tornava modelo identitário sul rio-grandense. Tanto que, em 1935, quando da comemoração do centenário da Revolução Farroupilha, houve o reconhecimento oficial da contribuição para o progresso do Estado dos "gaúchos de olhos e cabelos claros." Se, como lembra Pesavento (1994), no Rio Grande do Sul, os alemães se tornaram gaúchos pelos caminhos da modernização, em Santa Catarina eram os luso-brasileiros que corriam o risco de se tornarem "alemães" pelo mito do progresso.

A falta de integração, por inúmeros motivos, teria levado a uma preservação maior dos hábitos culturais teutos nas colônias catarinenses. Ainda que estudiosos da colonização teuta, como Giralda Seyferth, atestem que a característica de "isolamento e enquistamento" não dá conta de explicar a "emergência da etnicidade", contudo, mesmo essa autora - que trabalha na perspectiva da existência de uma assimilação já "bem visível" dos alemães e seus descendentes quando houve a campanha de nacionalização - reconhece que eram visíveis "as diferenças culturais e sociais etnicamente manipuláveis". (SEYFERTH, 1994) É com referência a essas diferenças que, por exemplo, Blumenau torna-se conhecida como a cidade "alemã", sinônimo de "quisto étnico" a ser nacionalizado em função da doutrina do pangermanismo. A propaganda nazista teria mobilizado uma parte expressiva dos teuto-brasileiros sob o discurso da superioridade racial, incentivado a preservação do Deutschtum (germanismo). Além da preservação que passava por uma série de atividades sociais, desde a escolarização na língua alemã aos clubes, como os de Caça e Tiro, temse desde 1929 em Santa Catarina a aparição de entidades partidárias a Hitler. (FLORES, 1997, p. 128-9. GERTZ, 1987, p. 63)

Mostrar a diferença na integração social dos teuto-brasileiros e o momento em que se iniciou o processo de nacionalização nos dois Estados tem, aqui, o interesse de ser o pano de fundo para pensar outra questão. Vimos anteriormente o grande esforço de políticos e intelectuais catarinenses em criar uma imagem positiva do luso-brasileiro do litoral a partir do anos 30, como isso representava um embate com as colônia alemãs e como o discurso que afirmava a vitória da colonização portuguesa encontrava motivação e sustentação no governo nacionalista de Vargas. Assim, parece estar-se diante de uma contradição: como em Santa Catarina se investe tão maciçamente na nacionalização em função do governo nacional, se tal governo era oriundo de um Estado que tinha tanto quanto aquele uma presença populacional teuta e nem por isso procurava com tanta ênfase nacionalizá-los, pelo menos não tão forte e antecipadamente como em Santa 
Catarina? Um entendimento possível passa, novamente, pela questão da fragmentação catarinense e pelo papel de destaque que os teutos tiveram na Primeira República, tanto econômica como politicamente. Mas, essas observações servirão para chegar-se a outra compreensão. Em Santa Catarina desde o início da República era a imagem do imigrante teuto que dava a conotação da identidade estadual. No Rio Grande do Sul, muito pelo contrário, a imagem do gaúcho como personagem típico, não tinha qualquer concorrente à altura, se é que tinha concorrente; ela reinava absoluta e soberanamente. Os teuto-brasileiros do Estado sul rio-grandense se não eram, em termos econômicos e políticos, ameaça às elites tradicionais, e ainda menos o eram em termo de identidade cultural.

A figura forte do gaúcho impedia que a colonização teuta maculasse a imagem do Rio grande do Sul perante a nação ou se constituísse em uma ameaça aos próprios gaúchos, no entanto tinha também o Estado sulino um problema em termos de brasilidade a solucionar. Se os alemães não tinham "germanizado" o Estado restava contudo, uma suspeita quanto à lusitanidade do gaúcho. Último Estado brasileiro ao sul, confrontando com Uruguai e Argentina, sua participação na historia nacional inicia-se já como fronteira, com as disputas entre Portugal e Espanha pelo domínio do território. A característica de ser limite cobria-lhe de uma imagem de nacionalidade vacilante por estar propenso à influencia externa. Via-se o Rio Grande do Sul com grandes ligações, bem como com identificação étnica e histórica, com a região do Prata. Assim, se não ocorreu uma antecipada e ferrenha nacionalização dos teutos, houve porém um investimento na lusitanização do gaúcho que é, não sem razão, anterior à própria Revolução de 30.

Além do congresso no qual Osvaldo Rodrigues Cabral apresentou o estudo Laguna e Rio Grande, o Instituto Histórico e Geográfico do Rio Grande do Sul organizou mais 3 congressos de história e geografia entre 1935 e 1945, atividade que pode ser compreendida dentro do que Gutfreind (1992) chamou de "triunfo do círculo histórico". Segundo a autora, a historiografia sul rio-grandense era marcada por duas correntes ou matrizes que balizavam as produções. Isto é, os escritos dos historiadores gaúchos estavam identificados ou às orientações da "matriz platina" ou às da "matriz lusitana". O "círculo historiográfico" configura-se como as novas diretrizes apresentadas pela "matriz lusitana" à historiografia a partir da década de 20, em função da vontade dos políticos gaúchos de terem maior atuação no âmbito nacional. A diferença entre as duas matrizes constava, primordialmente, do fato de aceitar ou não a influência platina como definidora na formação étnica e ética do Rio grande do Sul, identificando o gaúcho ao homem dos pampas. O que equivale à aceitação da participação espanhola na sua formação étnica inicial. Essa diferenciação de olhares 
produziu visões diferenciadas sobre questões fundamentais da história do Estado, seja quanto aos primeiros povoadores europeus, notadamente no que tange à carga lusitana à cultura e à índole de sua gente, ou mesmo quanto a acontecimentos bastante típicos de sua trajetória histórica, como as Missões e a Guerra dos Farrapos. A Revolução Farroupinha, por exemplo, com a reorientação dos anos 20, passou de separatista e platinista a fundamentalmente brasileira e federalista.

A aceitação da influência platina tornou-se, a partir da década de 1920, uma polêmica da qual a "matriz lusitana" saiu-se vitoriosa e predominou em grande medida, principalmente nos organismos oficiais, como o Instituto Histórico e Geográfico do Rio Grande do Sul - IHGRS, até por volta da década de 60. Foi aliás o Instituto criado à luz dessa matriz. Fundado em 1921 sob os auspícios do governo de Borges de Medeiros, o IHGRS já nasceu sob o signo da orientação historiográfica lusitana e sob a égide da política que a fez ascender. (GUTFREIND, 1992) Não bastava simplesmente construir uma nova base de representação dos acontecimentos passados, uma vez que havia a necessidade de garantir que tal representação ganhasse legitimidade, aceitação, que além de divulgada fosse reconhecida como a autêntica. Ou seja, que tivesse a capacidade de impor a recepção. Atribuição que cabia ao IHGRS pois, como uma instituição autorizada, forjada nos moldes do Instituto Histórico e Geográfico Brasileiro, fazia do discurso historiográfico luso a voz oficial, garantia e ampliava sua competência.

O gaúcho separatista, de índole libertária e independente, fruto de sua vida campeira dos pampas, cuja própria característica do meio teria forjado uma vida errante, era diferente dos demais brasileiros para ser apresentado como descendente do sangue português e exemplo de brasilidade e civismo. Imagem do sul que diferia do restante do país e precisava ser reformada, cabendo então à "matriz lusitana" o papel de criar uma interpretação histórica com idealismo nacionalista pautado no lusitanismo. Nesse processo de re-escrituração do passado, um dos elementos utilizados para garantir a brasilidade dos gaúchos era o povoamento inicial com as ocupações do território partidas de Laguna ou, como chamou Aurélio Porto (1931), O coeficiente lagunista na formação racial do gaúcho.

Este artigo não tem o interesse de rastrear a historiografia sul rio-grandense a fim de dar-lhe caraterísticas, nem mesmo o de analisar a produção historiográfica do IHGRS. O que move esta passagem pela historiografia gaúcha dos anos 30 e 40 é visitar as teses ${ }^{3}$ apresentadas nos congressos, no estrito propósito de perceber o outro sentido desta via de mão dupla. Ou seja, o quanto Laguna se tornava importante para tornar o Rio Grande do Sul um Estado de lusitanidade genuína. É dessa maneira que o texto de Cabral ganha maior sentido. Assim, salvo as primeiras 
ocupações do território e a origem dos primeiros ocupantes, não se estará examinando outros acontecimentos e passagens da história gaúcha que são "nacionalizados" e nem outros momentos nos quais a relação do Rio Grande do Sul com Laguna é também bastante estreita. Apresenta-se essa ressalva, porque não somente há outros momentos, objetos de análises dos trabalhos apresentados, nos quais a trajetória histórica do Estado sulino cruza-se com a lagunense, como também existe uma série de outras relações feitas para mostrar a brasilidade gaúcha, como a fundação do presídio do Rio Grande por Silva Paes, a vinda dos açorianos ou mesmo a montagem de certas condições de diferenciação do gaúcho brasileiro com o gaúcho platino. Do mesmo modo, não se trabalha o congresso realizado em 1945, comemorativo ao centenário da paz de Poncho Verde, por versar exclusivamente sobre a Revolução Farroupilha.

Como parte da grande festa comemorativa ao centenário da Revolução Farroupilha realizada em 1935, aconteceu de 1 a 9 de outubro daquele ano o Primeiro Congresso de História e Geografia Sul Rio-Grandense. Para esse primeiro certame historiográfico do IHGRS foram inscritas 32 teses, sendo que uma delas foi rejeitada. Ainda que comemorativo à Revolução Farroupilha, o Congresso não versava exclusivamente sobre ela. Há, aparentemente, uma busca por uma releitura total da história sul rio-grandense e uma breve observação da organização temática das secções propostas leva a esta constatação. O programa era composto de cinco secções (I-Formação do Rio Grande do Sul; II- História política; III- História militar; IV- Administração e economia; V- Ciências, letras e artes) e, sem dúvida, era a primeira a que ganhava maior importância, tendo inclusive sub-divisões (A- Formação do Rio Grande do Sul; B- Formação étnica; C- Formação social). Itens direcionados à Revolução Farroupilha foram propostos apenas dois, um na secção II e outro na secção III. Assim, tem-se no programa de secções de distribuição das teses, um longo itinerário que percorre praticamente toda a trajetória histórica do Rio Grande do Sul, não privilegiando o objeto festejado e sim a questão da formação gaúcha.

Pode-se ler nessa questão, a intenção de re-apresentar a história do Estado dentro da versão lusitana, por isto há mais interesse na "formação". Em seu discurso de encerramento do congresso, o presidente do IHGRS Leonardo Macedônia disse que, das 32 teses apresentadas, tinham "notável relevo" as que se ocupavam em estudar os aspectos geográficos, étnicos e sociais da formação do Rio Grande do Sul. (ANAIS, 1936, v. 1, p. 37) Não se deve esquecer que se tratava do primeiro encontro do gênero, integrando uma grande festividade, e a produção surgida a partir do congresso estaria sendo divulgada com grande intensidade não só ao público gaúcho como a convidados de outros Estados. O regulamento, assim como o programa de teses, foi distribuído como convite a um 
grande número de escritores brasileiros e várias organizações intelectuais enviaram comunicações solidárias, bem como algumas se fizeram representar por enviados que participaram do evento, dentre elas encontra-se a Sociedade de Geografia de Lisboa. Era uma forma de mostrar a lusitanidade ao restante do Brasil. (ANAIS, 1936, v. 1, p. 18-19)

O interesse em fazer brilhar a lusitanidade gaúcha pode ser observado também na recusa de uma das teses. Única rejeitada entre 32 apresentadas, a tese de Setembrino E. Pereda, Rasgos biográficos de Pedro José Vieira, não foi aceita sob alegação de ir contra o artigo $10^{\circ}$ do regimento do Congresso, o qual exigia que as teses fossem apresentadas na língua nacional. Há de se estranhar que um congresso estadual tenha a preocupação de assegurar de forma regimental que todas as atividades fossem feitas e redigidas na língua vernácula. Isso talvez fosse uma forma de evitar a participação de pesquisadores platinos, o que colocaria em evidência tanto uma ligação do Rio Grande do Sul com a Região do Prata naquele momento, quanto possibilitaria que os pesquisadores apresentassem visões da história sul rio-grandense distantes da versão lusitana. O que sabotaria o desejo de mostrar a brasilidade do Estado. É assim, por exemplo, que uma observação mais atenta revela que o motivo de recusa da tese do uruguaio não foi tão somente por ela estar redigida em espanhol mas, também, por apresentar opiniões que, aparentemente, não correspondiam aos princípios que norteavam o Congresso. Eduardo Duarte, secretário perpétuo do IHGRS, assim escreveu na ata da IV sessão:

\begin{abstract}
Diversos trechos da tese foram lidos a pedido de vários congressistas em torno dos quais foram feitos diversos comentários. $\mathrm{O}$ senhor Othelo, concordando com $\mathrm{o}$ senhor Osório opina pela repulsa da tese visto a mesma conter frases aviltantes ao Rio-Grandre-do-Sul e a uma das figuras de sua legenda, que foi Pedro José Vieira. Referiu-se, igualmente, aos sentimentos de aproximação dos países sul-americanos assunto ainda cogitado, ultimamente, com o convênio estabelecido com a república Argentina. (ANAIS, 1936, v. 1, p. 53)
\end{abstract}

Dentro da perspectiva do Congresso de mostrar ao Brasil o Rio Grande do Sul lusitano, surgem com muita intensidade os trabalhos versando sobre as primeiras ocupações portuguesas do território. É assim que aparece com grande visibilidade a relação Laguna e Rio Grande. A tese Memórias históricas e comentários, de J. O. Pinto Soares, por exemplo, cita as duas expedições de exploração do território que o capitão-mor de Laguna, Francisco de Brito Peixoto, organizou em 1715, seguindo determinação de Francisco de Távora, governador do Rio de Janeiro. Após essas primeiras expedições, seguiram-se a de 1726, chefiada por João de Magalhães, genro de Brito Peixoto, destinada a abrir uma estrada através do sertão até alcançar a Colônia do Sacramento, e a 
de 1735, confiada a Manoel Dias da Silva, com a mesma finalidade. A expedição de João de Magalhães é considerada, no texto de Pinto Soares, o marco da ocupação regular do território, mas é salientado que as investidas dos lagunenses sobre o Rio Grande do Sul já aconteciam antes mesmo dessa data. (ANAIS, 1936, v. 1, p. 218-9)

Já a tese apresentada por Manoel E. Fernandes Bastos, A fundação da freguesia de N. S. da Conceição do Arroio, colocava como ponto incontestável do estabelecimento regular português no Rio Grande do Sul a ocupação do Rio Grande por José da Silva Paes, ressalvando contudo que paulistas e lagunistas vinham de longa data alongando seus domínios sobre os pampas do sul. O Estado gaúcho, nesse texto, é visto como um território a ser explorado e ocupado a fim de estabelecer uma continuidade entre a Colônia do Sacramento, "sentinela avançada" do domínio português sempre ameaçada pelo inimigo, e Laguna, "espécie de quartel" de onde partiam as expedições, o que aconteceu ao estabelecerem a "estrada do litoral". Também diferente do texto de Pinto Soares, Fernandes Bastos diz, seguindo as indicações do historiador Borges Fortes, que a expedição de João de Magalhães teve unicamente caráter militar. Somente anos mais tarde dar-seiam expedições de povoamento, inicialmente com invernadas - ocupações temporárias das pastagens para o comércio do gado - e posteriormente com estâncias - ocupações definitivas das terras com o estabelecimento de famílias -. O autor data de 1732 a concessão das primeiras sesmarias, requeridas pelos lagunenses Manoel Gonçalves Ribeiro e Francisco Xavier Ribeiro, mas lembra que a data de concessão dos títulos não representa um marco da ocupação regular, visto que declararam os lagunenses estarem requerendo terras nas quais já estavam instaladas suas estâncias. A ocupação dos chamados "Campos do Tremandi", onde ficavam as primeiras sesmarias concedidas, fez-se, pelo menos até a fundação do presídio do Rio Grande por Silva Paes, do norte para sul, ocupando-se primeiro a região ao norte "pois era a mais aproximada de Laguna, de onde provinham os elementos que demandavam os pampas rio-grandenses”. Essa tese ao mostrar a importância de Laguna na ocupação territorial ao sul, apresenta vários nomes dos formadores da sociedade gaúcha dos primeiros tempos, gente lusitana que partia da vila de Brito Peixoto. (ANAIS, 1936, v. 1, p. 131-72)

Mais enfático que o próprio texto de Fernandes Bastos em mostrar a lusitanidade gaúcha via Laguna, é o parecer sobre sua tese assinado por Manuel Duarte, Aurélio Porto e F. Contreiras Rodrigues. Os analistas ressaltaram o valor do autor por garimpar documentos no esforço de encontrar o lastro inicial da conquista e povoamento dos campos de Tramandaí, onde encontra-se o “cerne primacial da população gaúcha”, e exaltaram os primeiros ocupantes que combateram e 
reteram o avanço espanhol, alargando as fronteiras e fundando a nação brasileira, destacando, o "avançado posto estratégico de Laguna" de onde, de velha data, homens de fibra "alongavam suas vistas para os pampas do sul, como se fosse a grande pátria futura.” (ANAIS, 1936, v. 1, p. 174)

Partindo da experiência obtida no evento de 1935, dois anos mais tarde o IHGRS realizou outro. Ocorrido na cidade de Rio Grande, entre os dias 19 e 24 de fevereiro de 1937, o Segundo Congresso de História e Geografia Sul Rio-Gandense festejava os duzentos anos da cidade sede. Mais especificamente comemorava-se o segundo centenário da chegada do Brigadeiro José da Silva Paes que, em 19 de fevereiro de 1737, transpôs a barra do Rio Grande e fundou o presídio militar Jesus, Maria, José.

Foram recebidas para o encontro 35 teses e, diferente do anterior, foram aceitas quatro estrangeiras, uma vinda do Chile, outra da Argentina e duas do Uruguai. Isso não quer dizer que o congresso de 1937 não se enquadrava na perspectiva de mostrar a brasilidade gaúcha. Muito pelo contrário, estava completamente de acordo com o intento de fazer brilhar o quanto de lusitano tinha o Estado sulino. O próprio objeto festejado se encaixa perfeitamente nessa intenção; festejava-se a ocupação portuguesa do território. O Brigadeiro Silva Paes, discursou o presidente do Instituto, era homenageado por protagonizar, juntamente com seus comandados, a incorporação do Continente de São Pedro à civilização brasileira e lusitana. (ANAIS, 1937, v. 1, p. 28)

É possível que a aceitação de teses estrangeiras fosse uma tentativa de evitar a polêmica ocorrida no congresso anterior. O regimento do segundo certame histórico gaúcho assegurava que as atividades seriam feitas em língua portuguesa ou espanhola mas tiveram os promotores outros cuidados. O programa de conteúdos das teses, por exemplo, diferente do primeiro congresso, era bem direcionado, não abrangendo a "totalidade" da história do Estado. O próprio presidente do IHGRS escreveu que os organizadores se empenharam em montar um programa de teses bem adequado aos acontecimentos relativos às ações do Brigadeiro José da Silva Paes no Rio Grande do Sul, visibilizando as glórias do militar lusitano. (ANAIS, 1937, v. 1, p. 6)

Mesmo partindo de um programa direcionado, deve-se levar em conta que a produção histórica que passava pelos canais do IHGRS caminhava no sentido de mostrar a brasilidade sulina. Assim, as ocupações lusitanas do território anteriores a Silva Paes também ganharam espaço e Laguna novamente surge com grande notoriedade. Nas teses apresentadas, as investidas dos laguneses nos pampas, continuavam sendo o material de sustentação das afirmações que faziam o Rio Grande do Sul um Estado que já nasceu sob o signo da brasilidade e na luta pela lusitanidade diante da ameaça espanhola. A cidade aparece em vários trabalhos e dois deles versavam mais 
detalhadamente sobre a relação Laguna e Rio Grande. Manoel E. Fernandes Bastos que, no primeiro congresso, já havia apresentado um trabalho no qual Laguna tinha grande destaque, voltou ao segundo encontro com a tese A estrada da Laguna ao Rio-Grande, mostrando a importância da rota para povoamento do sul. Apresentando um Rio Grande como objeto de disputa territorial entre Portugal e Espanha, Bastos lembra que mesmo com a fundação da Colônia do Sacramento em 1680 pelos portugueses, "continuava o continente de São-Pedro aberto a todas incursões do castelhano e a nova colônia, exposta aos ataques dos espanhóis, sem meios de se manter.” Assim, reforçava o pesquisador a importância das expedições que partiam de Laguna para explorar o sul, às quais davam início a uma "ligação mais acentuada entre Laguna e a Colônia do Sacramento, ao mesmo tempo que o território que ficava de permeio ia sendo explorado e conhecido," passando a efetiva ocupação, firmando a posse do que seriam mais tarde as estâncias. "Era o povoamento do RioGrande que se iniciava e a dominação portuguesa que se firmava no extremo Sul do Brasil.” O autor trabalha o itinerário da estrada, com o interesse de mostrar seu papel preponderante na colonização do Rio Grande, como artéria primeira que levou a lusitanidade ao sul, destacando o valor da estrada para o início do domínio português e da colonização do Rio Grande, bem como a maior relevância que esta ganhou depois da fundação de Silva Paes, uma vez que era de Laguna que partiam muitos dos víveres que abasteciam os soldados e as famílias de povoadores. (ANAIS, 1937, v. 1, p. 295322)

O outro trabalho em que Laguna aparece com distinção é Os lagunistas e Silva Paes, de Henrique Oscar Wiederspahn. O Autor narra as disputas hispânico-portuguesas no sul e o papel desempenhado por Laguna na colonização do Rio Grande, como frente de onde partiam as expedições. É um estudo bastante detalhado, liga os acontecimentos no sul do Brasil com o desenrolar dos fatos que movimentavam as coroas européias e, também, dá grande importância ao papel do capitão-mor da Laguna, Francisco de Brito Peixoto, para a expansão do domínio português no sul e consequentemente à colonização do Rio Grande. Sendo bastante completo, esse texto apresenta os vários desdobramentos de todo o arsenal que compõe a relação Laguna e Rio Grande: o caminho do gado, a concessão de sesmarias, as tropas que partiam de Laguna para a defesa de Sacramento. Além de tratar também da chegada de Silva Paes. (ANAIS, 1937, v. 3, p. 25-57)

Partindo do ponto de vista do texto apresentado por Oswaldo Rodrigues Cabral no congresso de 1940, há uma indicação bastante curiosa em Os lagunistas e Silva Paes. Wiederspahn mostra, assim como o autor catarinense, como o desenvolvimento do comércio do gado, com o estabelecimento da nova rota, representou a decadência para Laguna. "Este traçado [escreveu ele] 
selava de maneira definitiva a missão histórica de Laguna, que fora do eixo de comunicações no proveito dos sesmeiros do Viamão passava a simples entreposto marítimo até as primeiras décadas do século XIX”. Porém, o curioso é perceber que, muito diferente das intenções de Cabral, Wiederspahn germaniza o colonizador português e, no caso, os lagunistas. Escrevendo sobre a frota de João de Magalhães diz que esse era "natural de Braga, das regiões de preponderância nórdica na época em Portugal". Ao comentar sobre a tropa de Cristovão Pereira, lista alguns de seus homens, capitães e alferes, e completa: "eram em regra paulistas e lagunistas da velha estirpe dos bandeirantes, habituados às lides guerreiras com que seus ancestrais europeus haviam derramado o seu sangue nórdico desde as primitivas migrações célticas e germânicas dos séculos anteriores no Velho Mundo." Segundo o autor, no sul resplandecia o "Brasil dinâmico, empreendedor, industrializado, agricultor metódico e militarizado" que se diferenciava em muito do "Brasil estático do norte"; diferenciação resultante da superioridade étnica herdada dos primeiros povoadores "portadores dos atributos antropológicos e psicológicos das grandes migrações arianas ou nórdicas" que por meio da seleção tinha, na formação do Rio Grande do Sul, eliminado as "raças estranhas ao sangue dos primeiros povoadores e mesmo os tipos mestiços," daí a preponderância dos filhos gaúchos. (ANAIS, 1937, v. 3, p. 25-57)

O ano de 1940 foi o apogeu dos congressos do IHGRS, nenhum outro apresentou tamanha grandiosidade, nem mesmo o realizado em 1945 teve o esplendor e o brilhantismo do III Congresso Sul Rio-Grandense de História e Geografia. Solicitado ao Instituto pela prefeitura de Porto Alegre, o Congresso festejava o bi-centenário de fundação da cidade. Com o intuito de "recordar à geração presente e aos vindouros a obra magnífica dos antepassados", (ANAIS, 1940, v. 1, p. 7) foi ele o ápice da consagração do Instituto e da versão lusitana da história gaúcha. Entre os dias 5 e 16 de novembro, uma plêiade de intelectuais brasileiros e estrangeiros apresentaram uma grande quantidade de trabalhos, superando em número os dois congressos anteriores juntos. Enquanto os dois primeiros tiveram a inscrição de cerca de 30 teses cada, em 1940 foram recebidos 109 trabalhos, o que era alardeado pelos organizadores para mostrar o êxito daquele concurso.

São vários os quesitos que mostram o imenso sucesso do encontro. A começar pelo grande número de teses apresentadas e pela participação de pesquisadores de várias regiões do Brasil, da América do Sul e também do México, Cuba e Estados Unidos. Igualmente pelo apoio e participação de vários órgãos nacionais como: Instituto Brasileiro de Geografia e Estatística, Faculdade de Filosofia, Ciências e Letras da Universidade de São Paulo, Serviço do Patrimônio Histórico e Artístico Nacional, Museu Nacional, Museu do Ipiranga, entre outros. Como também a adesão de 
intelectuais de renome nacional como Gilberto Freyre, Mario de Andrade e Afonso D'Escragnole Taunay. (ANAIS, 1940, v. 1, p. 139-141) Mas, o grande destaque a mostrar o sucesso do congresso foi a participação do presidente Getúlio Vargas em seu encerramento. Acompanhado dos interventores do Rio Grande do Sul, Santa Catarina e São Paulo, Vargas prestigiou a última sessão do Congresso, na qual recebeu o título de Sócio Grande Benemérito do IHGRS. (ANAIS, 1940, v. 1, p. 295)

O programa de temas proposto para 1940 foi bastante variado e, devido à participação de pesquisadores de diversas regiões, ganhou em sua forma final uma diversificação ainda maior. Encontram-se os mais diferentes temas, inclusive não se limitando à história do Rio Grande do Sul. Mesmo assim, a questão da lusitanidade era marcante. Na verdade, tem-se um mega evento de divulgação pela notoriedade de um encontro de tamanha proporção e pelo grande número de participantes de fora do círculo de historiadores gaúchos. O próprio objeto de comemoração dava conta de mostrar a lusitanidade; era a capital gaúcha mostrando que nasceu de impulsos lusos. Festejava-se o início do povoamento da cidade por Jeronymo de Ornellas Menezes e Vasconcellos, português natural de vila de Santa Cruz, na ilha da Madeira. Dante de Laytano, presidente da comissão organizadora do evento, disse em seu discurso de abertura, que comemorar o bicentenário de Porto Alegre com o congresso era "prestar tributo de admiração à heróica e velha gente portuguesa que vinda dos Açores e metrópole incorporou o tão cobiçado 'continente do Rio Grande' ao resto destes Brasís de alma, sangue e coração lusitanos.” (ANAIS, 1940, v. 1, p. 141)

Até mesmo a participação de Gilberto Freyre, ao que parece, caminha no sentido de asseverar a lusitanidade gaúcha. Recepcionado quase com tanta pompa como Getúlio Vargas, Freyre foi conduzido a $6^{\mathrm{a}}$ sessão plenária por uma comissão e recebido de pé pela diretoria do Instituto. (ANAIS, 1940, v. 1, p. 316) Sugestões para o estudo histórico-social do sobrado no Rio Grande do Sul, o trabalho que apresentou, aparece nos anais do Congresso com distinção ímpar. No primeiro volume após breve apresentação da publicação pelo presidente do Instituto Leonardo Macedônia, surge o texto de Freyre, para em seguida vir toda a parte relatorial do evento, enquanto as demais teses são publicadas somente nos volumes seguintes. Não se deve subestimar essa atitude do Instituto. Intelectual de grande evidência naquele momento o autor de Casa grande senzala, ideólogo do Brasil "cadinho das raças", era voz autorizada a ditar o que era brasileiro. Assim, não é em vão o destaque que a personalidade e seu texto ganharam. Sugestões para o estudo históricosocial do sobrado no Rio Grande do Sul afirma que os sobrados encontrados no Estado sulino não diferem dos encontrados no resto do Brasil. Pois, para o autor, a paisagem arquitetônica brasileira 
de traços lusos apresenta pequenas variações regionais mas compõem-se de um "unitarismo ou unanimismo". No caso gaúcho as peculiaridades advindas do clima e dos colonizadores açorianos, ou ainda a possibilidade de influência dos povos vizinhos, não faziam menores aquele traço geral. "Sendo [escreveu Freyre] mais numerosas e evidentes as semelhanças dos sobrados do Sul com os sobrados do Norte e das demais regiões brasileiras em que esse tipo de arquitetura floresceu com característicos nitidamente portugueses." (ANAIS, 1940, v. 1, p. 12-20) Em outras palavras, a autoridade em termo de brasilidade assegurava que o sul era brasileiro tanto quanto o restante do país.

Além do texto apresentado por Oswaldo Rodrigues Cabral, que tinha sua cidade natal como objeto, Laguna é citada em vários outros trabalhos que apontavam para a lusitanidade sul riograndense, principalmente nos que versavam sobre os primeiros tempos da colonização. As primeiras expedições dos lagunistas são lembradas em diferentes teses, como, por exemplo, em $O s$ últimos fronteiros paulistas nas terras do Sul, de Omar Simões Magro, que ao lembrar os "grandes serviços" do capitão-mor de Laguna ao país, escreve que a Francisco de Brito Peixoto "se devem as primeiras tentativas de povoamento regular do Rio Grande do Sul e do estabelecimento ali da criação do gado, que tamanha riqueza havia de trazer ao Estado fronteiriço.” (ANAIS, 1940, v. 4, p. 2462) Também Henrique Boiteux, chamou a atenção para o fato de Laguna ser "o marco fundamental que serviu de irradiação e sustentação dos nossos limites meridionais”. (ANAIS, 1940, v. 4, p. 2235) Assim como Affonso de Escragnole Taunay escreveu sobre a importância de Laguna como apoio ao domínio luso na Colônia do Sacramento, afirmando: "não tardariam os lagunistas em demandar as terras do Sul, os páramos da grande lagoa meridional nos campos do Viamão. Nada mais justo do que a divisa adotada pela sua cidade; Ad meridiem Brasiliam duxi." (ANAIS, 1940, v. 4, p. 2721)

Quando da observação sobre os trabalhos apresentados no congresso de 1937 chamou-se a atenção para a tese Os lagunistas e Silva Paes, de Henrique Oscar Wiederspahn. O autor, possivelmente um descendente teuto, constrói a imagem lusitana do gaúcho via Laguna, porém vai além para encontrar na origem do lagunista a estirpe ariana. Essa relação seria impensável para os “inventores" da açorianidade catarinense por toda a disputa de identidade anteriormente comentada. O trabalho de Wiederspahn dá bem a conotação da diferença de como essa questão era colocada para os dois Estados do sul brasileiro. Tanto que os relatores do parecer sobre Os lagunistas e Silva Paes, liderados por João Borges Fortes, contestaram algumas das afirmações do autor, 
reconheceram a "origem lagunista", mas em nenhum momento tocaram na questão da ancestralidade primeira nórdica e ariana. (ANAIS, 1937, v. 3, p. 57-8)

A diferença que a imigração teuta representava para construção da identidade estadual de Santa Catarina e Rio Grande do Sul, pode ser observada por inúmeros indícios encontrados nas posturas dos intelectuais gaúchos e catarinenses. Aurélio Porto, por exemplo, figura de destaque da "matriz lusitana" da historiografia sul rio-grandense, era um exaltador do coeficiente lagunista na formação racial do gaúcho. No congresso de 1940 quando Cabral apresentou sua tese, na sessão plenária do dia 8 de novembro, após a leitura e aprovação do parecer, Porto solicitou um voto especial de louvor a Laguna, proferindo elogioso discurso ao lembrar que de Laguna partiram os desbravadores e povoadores do Rio Grande do Sul. (ANAIS, 1940, v. 1, p. 286) Era, no entanto, Aurélio Porto membro do Instituto Germano-Brasileiro criado em Porto Alegre em 1936. (GERTZ, 1987 , p. 66)

Os exemplos de Aurélio Porto e Henrique Oscar Wiederspahn servem para corroborar o que se apresentou anteriormente sobre a distinção com que se colocava a questão da lusitanidade em Santa Catarina e no Rio Grande do Sul. A forma como o caráter luso do nacionalismo é dado a ler nos Estados sulinos, mostra como em espaços sociais diferentes a realidade é construída distintamente, objetivada a partir de disputas próprias, nas quais a identidade afirmada como genuína reflete as necessidades e interesses dos que a fizeram aflorar. Nos dois Estados procurou-se forjá-la enquanto uma identidade histórica e em todos os dois casos havia a disputa com um "outro". Com relação a Santa Catarina esse outro, os colonos teutos e seus descendentes, melindrava a brasilidade do Estado perante o governo nacionalista. Para o Rio Grande do Sul o outro, a influência platina, maculava sua origem e formação lusa. Assim, em ambos os casos, os intelectuais engajados na lusitanisação, lançaram mão da história como o saber verídico a consolidar a identificação requerida. Ou, como lembra Eric Hobsbawm (1997, p. 21), como "cimento" a solidificá-la e a legitimar sua própria emergência. A história dava credibilidade à tradição criada e essa por sua vez justificava o poder dos que a "inventaram". Pode-se pensar em uma dupla acepção do "outro" nessa questão. Santa Catarina e Rio Grande do Sul procuravam apagar as identidades condenadas que cobriam suas imagens perante a nação e, assim, investem na afirmação de uma origem lusa inequívoca e dominante no sentido de nacionalizarem-se, eliminando as possibilidades de uma forte intervenção "alienígena" a compor suas formações, minimizando todo e qualquer traço que pudesse interferir na preponderância lusa de suas tradições. Tem-se, então, em termos nacionais a visão dos Estados sulinos como o "outro", a identidade renegada; 
vencer a diferença proscrita passava por um processo de eliminação do "outro" interno. É desse modo que Cabral encontrou a hora e a vez de fazer Laguna luzir: Santa Catarina mostrava sua lusitanidade, entre outros motivos, em função do governo nacionalista e nacionalizador que partia do Rio Grande do Sul, enquanto esse último vinculava sua origem lusa a uma cidade catarinense, como forma de legitimar o controle político sobre a União. Para tanto, em ambos os Estados os intelectuais engajados na arquitetura identitária, transformavam poder político em simbólico, "inventando" realidades com palavras, pois definiam o que eles eram ao construírem versões sobre seus passados.

\section{TWO-WAY STREET TO THE URGENT LUSITANITY: HISTORIOGRAPHICAL PLOTS THAT ENCLOSED THE SOUTHERN BRAZIL TO THE NATIONAL IDENTITY IN THE CONTEXT OF THE NEW STATE}

ABSTRACT: During the 30's and 40's of the twentieth century, the historiography of Santa Catarina and Rio Grande do Sul went through reformulations that sought to adapt the past of these two states to the nationalist standard of that time and also to build a version of the historical formation of the state that could dissipate with the suspicions that hovered over the ethnic profile and the standard identity of their populations in relation to Brazilianness. In both states there was a strong investment to the visibility of Lusitanian traditions, but the impulses that guided the historians of Santa Catarina and Rio Grande do Sul were not the same. The text "Laguna e Rio Grande", from Osvaldo Rodrigues Cabral, is taken as a guideline to reflect on such issues.

KEYWORDS: Historiography; Identity; Nationalization.

\section{NOTAS}

${ }^{1} \mathrm{O}$ presente artigo é uma versão compacta do primeiro capítulo de minha tese de doutorado. BITENCOURT. João Batista. Estado Novo, cidade velha: o governo ditatorial de Vargas desde Laguna. Porto Alegre. Tese (Doutorado em História) UFRGS, 2002.

${ }^{2}$ Em resposta à consulta do presidente do Conselho de Imigração e Colonização sobre a entrada de imigrantes em Santa Catarina, o Interventor Nereu Ramos fez a seguinte afirmação: “já não é passível de discussão a vantagem da introdução em nosso país dos colonos portugueses, mormente 
depois que o governo federal, em declaração do senhor Presidente da República, pôs de manifesto a sua orientação, no que concerne à política imigratória, no sentido da formação da nacionalidade, que é a luso-brasileira." Ofício do Interventor, Nereu Ramos, ao Presidente Conselho de Imigração e Colonização, João Carlos Muniz. Florianópolis, 04 de agosto de 1939.

${ }^{3}$ Os trabalhos apresentados nos congressos são classificados como teses ou memórias e, por vezes, como monografia. Porém aqui vou sempre me referir a teses, como uma forma geral de mencionar os trabalhos apresentados e, também, porque em nenhum momento encontrei referência dos organizadores quanto aos quesitos de distinção entre os trabalhos. Pois mesmo eles quando os tratavam no seu conjunto também os chamavam de teses.

\section{REFERÊNCIAS}

ANAIS do I Congresso de História e Geografia Sul Rio-Grandense. 1935. Porto Alegre: Livraria do Globo, 1936.

ANAIS do II Congresso de História e Geografia Sul Rio-Grandense. 1937. Porto Alegre: Livraria do Globo, 1937.

ANAIS do III Congresso Sul-Riograndense de História e Geografia. 1940. Porto Alegre: Livraria do Globo, 1940.

ARAÚJO, Hermetes Reis de. A invenção do litoral: Reformas urbanas e reajustamento social em Florianópolis na Primeira República. São Paulo: dissertação (mestrado em História) PUC-SP, 1989.

BASES para o Congresso da História Catarinense. Rev. Atualidades. Florianópolis, n. 4-5. Abr.Maio 1948.

BENJAMIN, Walter. Magia e técnica, arte e política: obras escolhidas I. $7^{\mathrm{a}}$ ed. São Paulo: Brasiliense, 1994.

BOSSLE, Ondina Pereira. História da industrialização Catarinense: das origens à integração no desenvolvimento brasileiro. CNI-FIESC, 1988.

BOURDIEU, Pierre. O poder simbólico. 2a ed. Rio de Janeiro: Bertrand Brasil, 1998. 
CABRAL, Oswaldo R. A vitória da colonização açoriana em Santa Catarina. Florianópolis: IOESC, s. d.

CABRAL, Oswaldo R. Discurso (Na colocação da pedra fundamental do monumento comemorativo do $2^{\circ}$ Centenário da chegada dos casais açorianos. Florianópolis, 20 de fevereiro de 1948) In: . Assuntos insulanos. Florianópolis: IOESC, 1948.

CABRAL, Oswaldo R. Laguna e outros ensaios. Florianópolis: IOESC, 1939.

CABRAL, Oswaldo R. Santa Catarina: história e evolução. São Paulo: Cia. Editora Nacional, 1937. (Biblioteca Pedagógica Brasileira - Brasiliana vol. 80)

CABRAL, Oswaldo R. Significado do açoriano no panorama social de Santa Catarina. Rev. Atualidades. Florianópolis, n. 12. Dez. 1948-b.

CAMPOS. Cynthia Machado. Controle e normatização de condutas em Santa Catarina (19301945). São Paulo: Dissertação (mestrado em História) PUC-SP, 1992.

CHARTIER, Roger. A história cultural: entre práticas e representações. Lisboa: Difel, 1990.

CORREAA, Carlos Humberto. Militares e civis num governo sem rumo: o governo provisório revolucionário de Desterro 1893-1894. Florianópolis: UFSC-Lunardelli, 1990.

CORRÊA, Carlos Humberto (Org.). Nereu Ramos. Florianópolis: FCC Edições - Associação Portobello de Cultura, 1988.

CUNHA, Idaulo J. Evolução econômico-industrial de Santa Catarina. Florianópolis: Fundação Catarinense de Cultura, 1982.

FLORES, Maria Bernardete Ramos. A farra do boi: palavras, sentidos, ficções. Florianópolis. Ed. Da UFSC, 1997.

FONTES, Henrique. Discurso. Rev. Atualidades. Florianópolis, n. 10. Out. 1948.

GERTZ, René E. O Fascismo no sul do Brasil. Porto Alegre: Mercado Aberto, 1987.

GUTFREIND, Ieda. A historiografia Rio-Grandense. Porto Alegre: Ed. Universidade/UFRGS, 1992.

HOBSBAWM, Eric e RANGER, Terence (Orgs.). A invenção das tradições. $2^{\mathrm{a}}$ ed. Rio de Janeiro: Paz e Terra, 1997. 
LE GOFF, Jacques. História e Memória. 3ª ed. Campinas: UNICAMP, 1994.

MAINGUENEAU, Dominique. Novas tendências em análise de discurso. $2^{\mathrm{a}}$ ed. Campinas: Pontes/UNICAMP, 1993.

MEIRINHO, Jali. A república em Santa Catarina de 1889 a 1900. Florianópolis: UFSCLunardelli,1982.

ORTIZ, Renato. Cultura brasileira e identidade nacional. $5^{\text {a }}$ ed. São Paulo: Brasiliense, 1994.

PESAVENTO, Sandra J. De como os alemães se tornaram gaúchos pelos caminhos da modernização. In: MAUCH, Cláudia e VASCONCELLOS, Naira (Org.) Os alemães no sul do Brasil: cultura, etnicidade e história. Canoas: Ed. ULBRA, 1994. P. 199-207.

PORTO, Aurélio. O coeficiente lagunista na formação racial do gaúcho. Rev. do IHGRS. Porto Alegre, n. 43-44, p. 169-86, 1931.

PIAZZA, Walter Fernando (Org.). Dicionário político catarinense. Florianópolis: Edição da Assembléia Legislativa do Estado de Santa Catarina, 1994.

SALLES, Iraci Galvão. Trabalho, progresso e sociedade civilizada: o Partido Republicano Paulista e a política de mão-de-obra (1870-1889). São Paulo: HUCITEC; Brasília: INL, 1986.

SEYFERTH, Giralda. A identidade teuto-brasileira numa perspectiva histórica. In: MAUCH, Cláudia e VASCONCELLOS, Naira (Org.) Os alemães no sul do Brasil: cultura, etnicidade e história. Canoas: Ed. ULBRA, 1994. Op. Cit. P. 11-27.

SEVCENKO, Nicolau. Literatura como missão: tensões sociais e criação cultural na Primeira República. $3^{\circ}$ ed. São Paulo: Brasiliense, 1989.

SILVA, Etienne Luiz. Desenvolvimento econômico periférico e formação da rede urbana de Santa Catarina. Porto Alegre: Dissertação (mestrado em planejamento urbano e regional) UFRGS, 1978.

SOUTO, Américo A. da Costa. Evolução histórico-econômica de Santa Catarina: estudo das alterações estruturais (século XVII-1960). Florianópolis: Centro de Assistência Gerencial de Santa Catarina - CEAG/SC, 1980. 